\title{
Formation of paremiological competence using mobile applications in a foreign language lesson in elementary school
}

\author{
M.A. Kulkova ${ }^{1 *}$, A.I. Giniatullina ${ }^{2}$, and N.V. Konopleva ${ }^{3}$ \\ ${ }^{1}$ Kazan (Volga region) Federal University, Kazan, Russia \\ ${ }^{2}$ Kazan (Volga region) Federal University, Kazan, Russia \\ ${ }^{3}$ Kazan (Volga region) Federal University, Kazan, Russia
}

\begin{abstract}
This article is devoted to the study of the conditions for the formation of paremiological competence in a foreign language lesson using mobile applications. Their usage allows to improve the quality of the process of learning foreign language thanks to the elements of interactivity. Mobile applications provide the ability of flexible adaptation of educational content to the individual needs of the teacher. Using the mobile application called 'Quizlet' is one of the most effective ways to form the paremiological component of communicative competence in schoolchildren at the initial stage of education. The success of using this mobile application in teaching English vocabulary is confirmed by the results of the pedagogical experiment.
\end{abstract}

\section{A problem statement}

The growing role of modern info communicational technologies in the educational process is noted nowadays. Mobile applications are becoming gradually more important in teaching foreign languages. The main competence formed in a foreign language lesson is communicative competence. One of the important components of communicative competence is the paremiological component. The formation of communicative competence literally depends on the formation of paremiological competence.

Nowadays, vocabulary learning is especially difficult for students. It is not always possible to achieve positive results and interest students with the help of the traditional form of education. Regarding this, the present study is aimed at finding new effective ways of using mobile applications in the process of forming paremiological skills in students at the initial stage of schooling.

\subsection{The objective of the work}

The problem stated above is reflected in the works of many domestic and foreign authors. Theoretical-methodological fundamentals of the research were the theoretical and methodological principles of educational psychology, developed in the works of I.A.

* Corresponding author: prof-ped.gpa@mail.ru 
Zimnyaya, B.V. Belyaev, as well as the theoretical theses of the process of the formation of paremiological skills in the methodology of teaching foreign languages, developed in the studies of A. Bruton, J. Coady, V.N. Douglas, R. Ellis, M. Hyde, M. Lewis, M.H. Long, R.K. Minyar-Belorucheva, G.V. Rogova, E.N. Solovova, S.F. Shatilov, A.N. Shchukin, V.A. Bukhbinder et al. From the position of the informational approach, the methods of teaching foreign languages using electronic educational resources were considered on the basis of the works of G. Dadny, N. Hockley, S. Vinditt, D. Hardisity, D. Eastment, A. Vitukhnovskaya, A.V. Osin, E.S. Polat, I.V. Roberta et al. Nevertheless, there is a small amount of research on the use of mobile applications in a foreign language lesson at school in the formation of paremiological competence.

\section{Results of the research}

To conduct the most effective research, we have identified a range of tasks that are aimed at theoretical substantiation and testing of the formation of paremiological competence using electronic educational resources. Within this study, the following tasks were set:

- consider the theoretical issues of using mobile applications in the educational process;

- analyze teaching material of English for 4th grades;

- describe the set of vocabulary exercises provided by the selected mobile applications;

- implement experimental teaching of English vocabulary using the mobile application 'Quizlet' in 4th grades and analyze the results.

Paremiological competence is the most important component of the cognitive base of students, which presupposes the same knowledge for subjects of a linguacultural society. The main functions of the cognitive base should include the following:

1) successful mastering of ready-made paremiological units;

2) formulating own phrases;

3) assessment of paremiological expressions of other participants in intercultural communication.

In addition, knowledge of vocabulary allows studying all types of speech activity better. Paremiological knowledge is a complex of linguistic data about foreign language and an understanding of the correct use of a word and actions with it [1].

In our research, we adhere to the following definition of paremiological competence: 'Paremiological competence is knowledge of the proverbial composition of the language and the ability to use it in the process of communication' [2].

All types of speech activity are important components in the study of vocabulary. However, many researchers argue that texts, especially written ones, act as the main component in this process. Firstly, the advantage of texts is manifested in the contextualization of new paremiological units. Secondly, the texts contain useful information that makes it easier to memorize vocabulary.

N. Schmitt notes that written discourse absorbs a large amount of paremiological material, which expands the vocabulary [3].

Researchers A. Bruton, J. Coady, V.N. Douglas, R. Ellis, M. Hyde, M. Lewis, M.H. Long considered the issues of mastering vocabulary, ways of solving issues related to identifying the meanings of vocabulary, issues of vocabulary selection for the development of vocabulary and its enrichment, issues related to the structure of paremiological competence, issues of developing exercises for the effective formation of types of speech activity $[4,5,6,7,8,9]$.

According to S. Thornberry, both in an oral and in a written situation (coherent text), there are many opportunities to identify a paremiological unit in a context with other vocabulary and on the basis of paremiological fields. Word usage is easy to learn when it is 
based on a thematic text, where there is a large number of words that are united by one concept - paremiological -semantic fields or paremiological-semantic groups [10].

P. Nation notes that there are two goals aimed at memorizing paremiological units in the text. Firstly, you need to understand the text in detail. Secondly, you should purposefully find and study linguistic phenomena in the text, train linguistic thinking and expand your vocabulary. Of course, the texts differ in complexity in terms of vocabulary. And here, in the analysis of such material, there happens not a simple study of paremiological units, but their study from the phonetic, morphological, syntactic sides, due to which students studying the language use reference literature [11].

Learning vocabulary and speech activity is permissible if there is a language system and the following pattern is considered: theoretical knowledge about vocabulary is introduced, paremiological language skills, then speech skills and, ultimately, speech skills are mastered. Indeed, the introduction of theoretical information about vocabulary at the initial stage allows the formation of language, but not speech skills at the next stage [12].

Researcher B.A. Lapidus argues that the traditional method 'first form and semantics, then function and purpose' was ineffective, since the difference between form-semantics and the function of a paremiological unit in a certain communicative situation in the formation of paremiological competence complicates the transfer of this skill into speech activity, namely speaking [13]. But the principles of a consciously practical approach (oral anticipation, situational awareness, the principle of reliance on the native language) positively influenced the formation of an intensive approach.

According to E.I. Passov, 'Presentation of the function of a foreign language word has a positive effect on the assimilation of formal connections of foreign language vocabulary, thus, students have a need to use a paremiological unit, which allows them to involuntarily remember it' [14].

In addition, E.I. Passov notes that paremiological units, along with form and semantics, have a speech function. Paremiological units have an associative relationship with these functions, which is reproduced in memory during the appearance of a speech task when it is given to the speaker. The functionality allows you to master the material in the process of speech activity.

E.I. Passov identifies the following stages in the formation of paremiological competence:

1) semantisation of paremiological units;

2) automation of paremiological units;

3) subsequent improvement of paremiological competence.

But, it is worth mentioning that he also highlights 6 important and general stages that are needed when introducing a new word:

1) understanding the word in the text;

2) clarification of the semantics of the word;

3) imitative use of a word in a phrase;

4) independent use of the word in context;

5) combination (use of a word with other words);

6) the use of the word [15].

Moreover, the main result of the formed judgments was the creation of a paremiological approach in teaching foreign language vocabulary, with the help of which paremiological errors seem important along with grammatical ones.

According to the researcher M. Lewis, a huge number of reproducible paremiological units in the paremiological approach is the basis for novelty in the student's language [9].

R.P. Milrud notes that the use of electronic educational resources will allow us to achieve a communicative task in the classroom [16]. Researchers V.P. Sysoeva, A.I. Tatarintseva, N.V. Nesterova and E.S. Polat and others in their works, where they touch 
upon the issue of informatization of education, argue that it is electronic educational tools that are an effective way of interactivity [17].

Electronic educational resources are an effective means for the successful assimilation of paremiological material in the course of learning. They can be applied at every stage of working with paremiological units, and they incorporate an endless number of exercises for learners. The ways and possibilities of using the Internet are limitless, as they present a wide range of opportunities for learners to study anywhere and anytime [18].

In addition, researcher L.A. Podprigorova believes that the use of electronic educational resources and Internet resources should not be an end in themselves. They should be a part of the learning process, cooperating with the traditional ways of learning.

Foreign researchers of the integration of information technologies G. Dadney and N. Hockley introduced the concept of 'teacher's mobile competence' to identify the level of knowledge and skills of a teacher when using information technologies. This mobile competence of a teacher acts as an integral component of ICT competence. The importance of considering this competence as a part of the teacher's ICT competence is expressed by the standards of education of the new generation. It incorporates the knowledge, skills and abilities that are necessary to assess the impact of information technology on the teaching of foreign languages [19].

The main goal of the teacher is to create conditions for successful practical language acquisition for each student and to choose the correct teaching methods for the manifestation of the student's activity and creativity when using electronic educational resources [20].

Innovative pedagogical technologies, namely project methodology, learning in collaboration, usage of electronic educational resources, allow a person-centered approach in the learning process, implement the differentiation and individualization of learning while considering the capabilities of students.

The question of the successful application of information technologies in the educational process has become relevant in pedagogical science and practice. Researchers such as C. McLean, B. Hunter, S. Papert and others were the first to highlight the problem of developing a holistic computerized learning system. As they note, information technology can be applied in any educational discipline [21, 22, 23].

Electronic educational resources primarily implement such a didactic principle as visualization. Typically, the use of audiovisual materials reduces the required learning time by $40 \%$ and increases the amount of information learned by $20 \%$.

In the book called 'Internet', foreign authors Scott Winditt, David Hardisity and David Eastment consider tasks that are related to the formation of skills of searching and processing information from Internet resources. Moreover, the authors describe certain tasks aimed at the development of paremiological competence, which is based on the development of skills in the extraction and processing of data [24].

Another researcher N.M. Koptyug singles out the following forms of working with Internet resources:

- usage of Internet resources when introducing new material;

- independent work of students with Internet resources during the preparation of reports and other assignments;

- participation in international projects;

- development of your own sites;

- teacher's communication with colleagues, experience exchange [25].

Thus, we believe that when using mobile applications, the teacher's role is improved, the goals of which are to convey the necessary information, choose a useful electronic application, help and shaping of the personality of students. In addition, in our opinion, the use of mobile applications should not replace traditional ways of teaching. On the contrary, 
traditional and modern methods must be used in conjunction with each other at any stage of the training.

Mobile applications, which are based on embedded Internet programs, enable the user (teacher) to adapt the content for their own specific requests and needs. The development of a methodology for composing paremiological tasks using electronic applications was considered by such researchers as O.E. Yankina, K.V. Aleksandrov, E.A. Blagushina, I. Yu. Nizovaya and others [17].

Having analyzed the educational-methodological kits (EMK) of foreign and Russian authors, we concluded that the EMK contains a small number of exercises for consolidating and practicing new paremiological units. Moreover, the textbooks do not consider the use of mobile applications. That is why we have chosen the 'Quizlet' resource, which is optimal for teaching the paremiological units of the English language.

Among modern educational resources, one of the most popular is the mobile application called 'Quizlet'. It includes a variety of tasks for working on paremiological units without a contextual environment at the stages of training and consolidation of paremiological units. The main reason for choosing this electronic educational resource was the presence of exercises to consolidate the form of the paremiological unit (graphic also), which are not enough in the English textbook that we analyzed. The Quizlet mobile app has such an important feature as the ability to conduct reflection, which is not typical for other resources.

The working principle of the resource does not cause any difficulties: initially, the teacher fills out a table with paremiological units, gives an interpretation, translation from a foreign language into his native language, then selects means for visual semantization of this paremiological unit. As a rule, to develop a lesson on a given topic, groups of words are included based on a specific thematic core (for example, food, verbs of movement, pieces of furniture, etc.), as well as vocabulary that is used in a specific text.

All information on the student's work is saved in the system and is reflected in a specific file for the teacher. There are some peculiarities of working with the Quizlet resource. Firstly, users are registered, which means that each user must have an account in the program. In addition, the organization of work with this mobile application is carried out in the form of sessions. Secondly, after registration is completed, the teacher can create new teaching material or include existing one. Thirdly, all the changes made with the training material remain in the system in a specific database and can be accessed by all registered persons. The student himself enters the system at the address given by the teacher, does tasks and exercises. All its results also remain in the system, in a specific database.

The exercises that we created in Quizlet were designed based on the principle of a "spiral" - from simple to complex - and involve working with paremiological units according to the following steps:

1) the stage of identifying the meaning of a new paremiological unit;

2) the stage of memorizing new vocabulary;

3) the stage of practicing, training new words and reproducing their graphic image;

4) the stage of checking the understanding of new vocabulary.

Now we want to present examples of exercises that we created using an electronic educational resource.

At the beginning of the work, students should get to know new paremiological units using double-sided flash cards. On one side there is a picture and translation in Russian. On the other side there is a translation in English. Moreover, cards can be turned over an unlimited number of times. After familiarization with the new paremiological units, the student is given a memorization exercise, namely translation from English into Russian. In tasks where the memorization of a graphic image of a paremiological unit is given, a translation of a new word from Russian into English should be made. And here the 
following variants of the student's answer are possible: 1) the student completes the task and moves on; 2) the student chooses the option "I don't know", in which case the resource gives the correct answer and the student types this answer on the keyboard; 3 ) the student can do the task incorrectly and the system shows him the correct answer. Having done the following tasks with the word, the student can perform the task once again if a mistake was made. After completing all the tasks, the stage of verification (control) of mastering new vocabulary begins. And here a True / False task is proposed, which is usually used in tasks related to the text. The tasks presented were applied under the guidance of a teacher in the classroom. And finally, two vocabulary games will be given to students for homework.

To confirm our hypothesis that the formation of paremiological skills in the process of teaching a foreign language at the initial stage of learning can be successfully implemented using electronic educational resources, a pedagogical experiment was conducted. In the pedagogical experiment, 50 students of 4th grades took part. 4 subgroups of 4 th grades were selected: 2 control subgroups (13 and 13 people) and 2 experimental (12 and 12 people).

The pedagogical experiment was held in three stages:

1) the ascertaining stage, which included a questionnaire survey of students and the identification of the initial level of understanding of paremiological tasks by students;

2) the formative stage, where the work was directly connected with the use of electronic educational resources in teaching foreign language vocabulary at the middle stage of education;

3) the control stage, in which the analysis of the effectiveness of the use of electronic educational resources in teaching vocabulary in foreign language lessons of 4th grades was carried out.

At the beginning of our pedagogical experiment, we conducted a survey among students of 4th grades in order to determine the level of students' interest in learning English and the difficulties that students face when learning new paremiological units. The survey was conducted in writing form and was submitted anonymously.

According to the results of the survey, the following data was found out: to the questions "Do you like learning English?" and "Is it difficult for you to learn new words?" out of 50 interviewed 45 students answered that they like to learn English, while 27 students have difficulties in learning new paremiological units, and the remaining 23 do not.

The next stage of the pedagogical experiment was preliminary testing among grades $4 \mathrm{~A}$, $4 \mathrm{~B}, 4 \mathrm{C}$ and $4 \mathrm{D}$ to identify the initial level of vocabulary proficiency, as well as to determine the control and experimental groups of our study. Classes 4A, 4B, 4C and 4D are taught according to the book named Spotlight 4 "English in focus", so the subjects were offered a vocabulary dictation on the current topics, which was compiled by the author of the book. 16 words were given for the translation: 8 words from Russian into English, and 8 words from English into Russian.

After finishing the dictation, we rated the students' work. We considered the absence of an answer, the wrong answer, and the presence of spelling errors as a mistake. After completing the task, the following data were obtained (Table 1).

Thus, the result of the primary diagnosis revealed an insufficient formation of paremiological skills in grades $4 \mathrm{C}$ and $4 \mathrm{D}$. Regarding this, these classes were selected as participants in the experimental group, in which a mobile application was used to teach foreign language vocabulary. Grades $4 \mathrm{~A}$ and $4 \mathrm{~B}$ were chosen by us as participants in the control group. 
Table 1. Initial Test Results in 4A, 4B, 4C, and 4D.

\begin{tabular}{|l|l|l|l|l|}
\hline Mark & 4A (13 students) & 4B (13 students) & 4C (12 students) & 4D (12 students) \\
\hline$\ll 5 »$ & 3 & 2 & 1 & 2 \\
\hline$\ll 4 »$ & 1 & 2 & 2 & 1 \\
\hline$\ll 3 »$ & 5 & 4 & 4 & 5 \\
\hline$\ll 2 »$ & 4 & 5 & 5 & 4 \\
\hline
\end{tabular}

In the experimental group, on the lesson, we used vocabulary exercises created by us with the help of the resource 'Quizlet' to practice and consolidate new vocabulary. Students completed the following tasks: working with cards (an uninterrupted way of semantization), memorizing words (translation from Russian into English and vice versa), the 'Writing' task (writing a word using its translation from Russian into English), spelling task (spelling the English word they heard), a test (students were asked 5 questions for a written answer, 5 questions involving the selection of vocabulary, 5 questions with a choice of answer, 5 questions of the 'true/false' type (True / False)). As a homework assignment, the students were given a link to the resource 'Quizlet', where they were offered vocabulary games.

At the control stage of the experiment, the final testing of the control and experimental groups was carried out in order to verify the effectiveness of the 'Quizlet' mobile application in the formation of the English language paremiological competence.

Regarding the noted difficulties students had while studying paremiological units, as a control of the assimilation of the studied vocabulary, the students were offered the following tasks: spelling dictation, translation of paremiological units from English into Russian and vice versa. 20 paremiological units were selected from the glossary in the textbook. The main parameter of the choice of words was the variable frequency of speech (nouns, adjectives, verbs). Each assignment was graded autonomously. According to the results of the final testing, a comparative analysis of the results of the final control work in the experimental and control groups was carried out. The results are presented (Table 2).

Table 2. Control Test Results in $4 \mathrm{~A}, 4 \mathrm{~B}, 4 \mathrm{C}$ and $4 \mathrm{G}$

\begin{tabular}{|l|l|l|l|l|l|l|l|l|l|l|l|l|l|}
\hline $\begin{array}{c}\text { Mar } \\
\mathbf{k}\end{array}$ & \multicolumn{3}{|c|}{ 4A(13 students) } & \multicolumn{3}{c|}{ 4B(13 students) } & \multicolumn{3}{c|}{ 4C(12 students) } & \multicolumn{3}{|c|}{ 4D(12 students) } \\
\cline { 2 - 14 } & $\begin{array}{c}\text { CG } \\
\mathbf{t}\end{array}$ & $\begin{array}{c}\text { Tra } \\
\mathbf{n}\end{array}$ & $\begin{array}{c}\text { Tra } \\
\mathbf{n}\end{array}$ & $\begin{array}{c}\text { Dic } \\
\mathbf{t}\end{array}$ & $\begin{array}{c}\text { Tra } \\
\mathbf{n}\end{array}$ & $\begin{array}{c}\text { Tra } \\
\mathbf{n}\end{array}$ & $\begin{array}{c}\text { Dic } \\
\mathbf{t}\end{array}$ & $\begin{array}{c}\text { Tra } \\
\mathbf{n}\end{array}$ & $\begin{array}{c}\text { Tra } \\
\mathbf{n}\end{array}$ & $\begin{array}{c}\text { Dic } \\
\mathbf{t}\end{array}$ & $\begin{array}{c}\text { Tra } \\
\mathbf{n}\end{array}$ & $\begin{array}{c}\text { Tra } \\
\mathbf{n}\end{array}$ \\
\hline$\ll 5 »$ & 1 & 3 & 3 & 2 & 3 & 2 & 5 & 8 & 6 & 4 & 10 & 3 \\
\hline$\ll 4 »$ & 6 & 1 & 2 & 6 & 2 & 1 & 3 & 0 & 3 & 3 & 0 & 3 \\
\hline$\ll 3 »$ & 0 & 6 & 4 & 0 & 6 & 5 & 1 & 2 & 0 & 2 & 1 & 3 \\
\hline$\ll 2 »$ & 6 & 3 & 4 & 5 & 2 & 5 & 3 & 2 & 3 & 3 & 1 & 3 \\
\hline
\end{tabular}




\section{Conclusions}

According to the analysis of the results of the final testing in the control group, the level of proficiency in paremiological units, which was achieved in the course of learning the studied paremiological topic, turned out to be lower than in the experimental group, given the fact that, according to the results of preliminary testing, the initial level of proficiency in English in the control group was higher than in the experimental one. After analyzing the results of our pedagogical experiment, we concluded that the use of electronic educational resources in foreign language lessons when teaching foreign language vocabulary arouses students' interest in the English language, improves the quality of mastering paremiological material and individualizes the educational process, and also helps to exclude subjective assessment in the learning process.

Thus, the formation of a foreign language paremiological competence using the mobile application 'Quizlet' is effective and indicates an increase in the level of motivation for learning a foreign language, faster memorization of new vocabulary and compliance with modern achievements of infocommunicational technologies.

The work is performed according to the Russian Government Program of Competitive Growth of Kazan Federal University.

\section{References}

1. A.N. Shamov, Principles of teaching lexical side of foreign speech, Foreign languages at school, 4, 2-9 (2009)

2. N.V. Murashova, Formation of paremiological competence of foreign students of humanitarian profiles, Extended abstract of PhD dissertation (2020)

3. N. Schmitt, A Fresh Approach to Vocabulary: Using a Word Knowledge Framework, RELC JOURNAL, 26, 86-94 (1995)

4. A. Bruton, Practical Reading, 245 (2013)

5. J. Coady, Second Language Vocabulary Acquisition, British Council, 176 (2010)

6. H. Douglas, Principles of language learning and teaching, 410 (2007)

7. R. Ellis, Analysing Learner Language, 263 (2009)

8. M. Hyde, Practical lessons in Use of English, Oxford: Pearson Longman, 163 (2012)

9. M. Lewis, Implementing the lexical approach: Putting theory into practice, 223 (2008)

10. S. Thornbury, How to teach vocabulary, 186 (2002)

11. P. Nation, New ways in teaching vocabulary, 218 (1994)

12. E.V. Varlamova, E.A. Tulusina, Z.M. Zaripova, Lexical Semantic Field as One of the Keys to Second Language Teaching, Interchange, 1-11 (2016)

13. A.A. Leontev, Language and speech activity in general and educational psychology: Selected pedagogical works, 448 (2001)

14. E.I. Passov, Fundamentals of communicative methods of teaching foreign language communication, 276 (1989)

15. E.I. Passov, Fundamentals of methods of teaching foreign languages, 216 (1977)

16. A.A. Mirolyubov, General methodology of teaching foreign languages in secondary school, 364 (2006) 
17. V.P. Demkin, Classification of educational electronic publications: basic principles and criteria, Open and distance education, 11(22), 3-6 (2003)

18. N.V. Konopleva, N.V. Aleksandrovich, Digitalization of Education, Digitalization of Education: History, Trends and Prospects" (DETP 2020), 835-838 (2020)

19. G. Dudeney, How to Teach English with Technology, 192 (2007)

20. M.A. Kulkova, Development of the lexical competence of foreign students in the RFL class using corpus technologies, 113-118 (2020)

21. K. Maclean, Computers at school, 182 (2008)

22. B. Hanter, My pupils are working at computers, 237 (2009)

23. S. Papert, The Children's Machine: Rethinking School in the Age of the Computer, 195 (1992)

24. S. Windeatt, D. Hardisty, D. Eastment, The Internet, 136 (2000)

25. N.M. Koptyug, Internet projects as part of the school program, Foreign language at school, 2, 29 (2008) 